\title{
News From the Chapters
}

The spring conference of the New England Chapter of ACRL met on April 2-3, 1976, at the Sheraton Islander in Newport, Rhode Island. In her opening remarks, Diane Lutz, chapter president, elaborated on the theme, "People Power: Management of Human Resources Development." She noted the impact of budget reductions on library staffing patterns and the resulting necessity to review both the problems and development of existing staff.

William Hunzeker, assistant professor of management information science at New Hampshire College, put things in perspective as he discussed the role of the library as it relates to the mission of the university which, in turn, relates to the total system of society. He stressed the importance of academic libraries setting their goals in support of the larger system.

Sheila Creth, assistant director for personnel, University of Connecticut, imparted her enthusiasm for staff development programs. First noting the difference between staff development programs and continuing education programs, she went on to discuss the steps involved in the "in-house" design of a staff development program. In relating the quality of the staff to the library's mission to provide quality services, she pointed out the critical importance to the staff and the institution of effective programs of staff development.

Job design was the focus of remarks by Mary Chatfield, associate librarian, Harvard Business School, as she discussed "Personnel Utilization Management in the Academic Library."

At the business meeting, ACRL/NEC officers for 1976 were introduced: Diane Lutz, president; Irma Johnson, vice-president/president-elect; Anne Conway, secretary; Roberta Beverly, treasurer; and Mary Thatcher and Joan Stockard, members-at-large.

The Saturday morning session opened with a presentation by $\mathbf{E}$. J. Josey, chief, Bureau of Academic and Research Libraries, New York State Education Department, concerning affirmative action in academic libraries.

The conference concluded with some observations by Eric Moon, president, Scarecrow Press. In his discussion entitled "A Potpourri of P's," Mr. Moon covered aspects of professionalism and personnel. All presentations were taped during the conference. Anyone interested in obtaining a copy of the tapes should contact Diane Lutz, New Hampshire College. 출

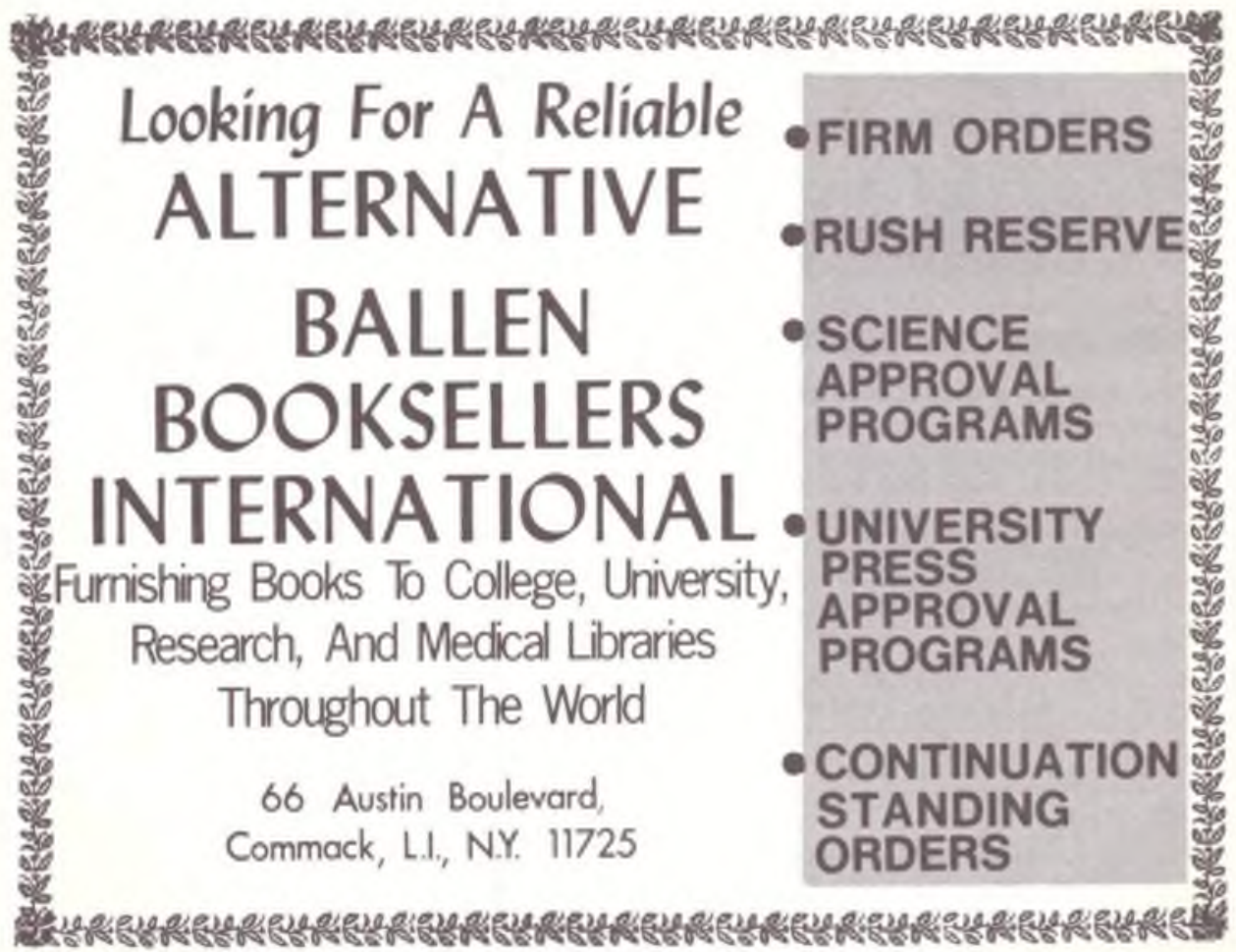

